\title{
Evaluation of the Inclusive Program and Its Suitability to Receiving Teachers Competence and Practices
}

\author{
Juanito N. Infante Jr.
}

\begin{abstract}
In the Philippines, students with special needs are now given the privileged to be mainstreamed. However due to these changes, the receiving teachers now are tasked to accept students whose dynamics in learning and behaviors are different from the rest, thereby adding difficulty in the regular tasks that are given to them, a task that they are not familiar with.

Hence, the researcher saw it appropriate to look into the competence and personal qualities of receiving teachers assigned to handle students under the Inclusive program that will eventually be a gauge to improve the offering of the Inclusive Education Program in the Division of Surigao through a faculty development program for receiving teachers.

The descriptive quantitative survey method was used in this study. Research findings shows that the receiving teachers is knowledgeable of the Inclusive program however there was no relevant trainings.

This study is an eye-opener for people in the academe on the importance of training teachers on differentiated learning and that continuous upgrading of skills that are beneficial to the stakeholders.
\end{abstract}

Keywords - Education, Special Needs, Trainings, Teachers Competencies, Inclusive Education

\section{INTRODUCTION}

The Philippine Educational System has been doing rigid changes in its offering to the Filipino students brought about by the changing educational landscape. The department has adapted a program known as $\mathrm{K}-12$, this is the adding of the additional 2 years in the basic education. The changes prompted in the strengthening of the Special Education Program "inclusion" which was designed to "meet the unusual needs of exceptional student that requires special materials, teaching techniques, equipment and facilities" ( Hallahan, Kauffman and Pullen ,2012).

The daunting task of preparing teachers to work with individuals with disabilities has become more challenging and more rigid. A lot of preparation needs to be accomplished such as: the individualized instruction, additional take-home activities, exams and others, activities (Nougaret, Scruggs and Mastropieri, :2005).

Special education has changed, and also the role of the special education professionals. The changing milieu of the educational landscape gave new roles, new task and new responsibilities to become competent educators. (Polloway, Patton, Serna and Bailey;2012)

It has been 9 years since Department order 72, s, 2009 or

Juanito N. Infante Jr., Professor, St Paul University Surigao, Philippine the "Inclusive Education as a Strategy for Increasing Participation Rate of Children was mandated. Filipino students are now given the privileged to be mainstreamed.

However due to these changes, the receiving teachers now are tasked to accept students whose dynamics in learning and behaviors are different from the rest, thereby adding difficulty in the regular tasks that are given to them, a task that they are not familiar with.

According to Clough and Garner (2003) as mentioned by Hodkinson (2016), inclusion for some children are stalled because the "educational system is not fit to include children with special needs owing to the barriers of lack of knowledge, lack of will, lack of vision, lack of resources and even lack of morality

Hence, the researcher saw it appropriate to look into the competence and personal qualities of receiving teachers assigned to handle students under the Inclusive program that will eventually be a gauge to improve the offering of the Inclusive Education Program in the Division of Surigao through a faculty development program for receiving teachers.

\section{A. Tables}

Table 1 Out of the 10 items presented only items Nos. 1 and 3 "I am aware of the Inclusive Education program" and "I was informed that I will have students who are under the Inclusive education Program" received the highest mean score at 2.60 with the verbal interpretation of Agree. However, it was mentioned that although trainings are given it was not really focused on the needs of special students.

In the study conducted by Woodstock \& Vialle (2010) they mentioned the discrepancy of how teacher teaches students with learning disabilities and students without learning disabilities. The strategy that was commonly used by the Special Education Teachers normally favors those who do not have learning disabilities.

However, DO. 72 s, 2009 item no. 6 mandates that training on inclusive education and technical assistance should be provided by the department, and a regular monitoring on the implementation of the program should be conducted to determine the effectiveness of the program, which is not currently done at the moment.

Hence, the lack trainings given to receiving teachers dampens the teachers' ability to instruct using relevant instruction in the class.

TABLE I 
Mean Percentage Distribution of Trainings given to ReCeiving TEACHERS.

\begin{tabular}{|c|c|c|}
\hline Items & MEAN & VI \\
\hline $\begin{array}{l}\text { 1. I am aware of the Inclusive } \\
\text { Education program. }\end{array}$ & 2.60 & A \\
\hline \begin{tabular}{ll}
\multicolumn{1}{c}{$2 . \quad$ I was trained to handle } \\
students & Under the Inclusive \\
Education program.
\end{tabular} & 1.70 & $\mathrm{SD}$ \\
\hline $\begin{array}{l}\text { 3. I was informed that I will } \\
\text { have students who are under the } \\
\text { Inclusive education Program }\end{array}$ & 2.60 & A \\
\hline $\begin{array}{l}4 . \quad \text { I was given instruction and } \\
\text { information on how to handle these } \\
\text { kind of students. }\end{array}$ & 1.30 & $\mathrm{SD}$ \\
\hline $\begin{array}{l}5 . \quad \text { I am sent to attend } \\
\text { professional development, team } \\
\text { planning and data analysis meetings to } \\
\text { improve understanding of the } \\
\text { Inclusive program. }\end{array}$ & 1.40 & $\mathrm{SD}$ \\
\hline $\begin{array}{l}\text { 6. I am sent to participate in } \\
\text { structured and informal leaming and } \\
\text { development opportunities for } \\
\text { Inclusive program }\end{array}$ & 1.40 & $\mathrm{SD}$ \\
\hline $\begin{array}{l}\text { 7. I was taught to assess } \\
\text { students under the inclusive program } \\
\text { through formal and informal methods. }\end{array}$ & 1.40 & $\mathrm{SD}$ \\
\hline $\begin{array}{l}\text { 8. I promote growth in all } \\
\text { students through the integration of } \\
\text { academic, psychological, physical, and } \\
\text { social leaming under the inclusive } \\
\text { program. }\end{array}$ & 1.80 & $\mathrm{D}$ \\
\hline $\begin{array}{l}\text { 9. I was trained to have a strong } \\
\text { instructional management skill to help } \\
\text { students under the inclusive program. }\end{array}$ & 1.80 & $\mathrm{D}$ \\
\hline $\begin{array}{l}\text { 10. I was trained to have a strong } \\
\text { classroom management skill to help } \\
\text { students under the inclusive program. }\end{array}$ & 1.80 & $\mathrm{D}$ \\
\hline Overall Weighted Mean & 1.78 & $\mathrm{D}$ \\
\hline
\end{tabular}

TABLE II

MEAN PERCENTAge Distribution of LEARNING ENVIRONMENT USED/CREATED BY THE RECEIVING TEACHERS UNDER THE INCLUSIVE EDUCATION PROGRAM

\begin{tabular}{|l|c|c|}
\hline \multicolumn{1}{|c|}{ Items } & MEAN & VI \\
\hline 1. I taught to create an environment of trust & 3.00 & $\mathrm{~A}$ \\
\hline $\begin{array}{l}\text { 2. I utilize data from initial assessments to drive } \\
\text { instruction and intervention. }\end{array}$ & 2.60 & $\mathrm{~A}$ \\
\hline $\begin{array}{l}\text { 3. I use research based instruction for my students } \\
\text { under the Inclusive Education Program }\end{array}$ & 2.40 & $\mathrm{D}$ \\
\hline $\begin{array}{l}\text { 4. I. create a safe classroom characterized by } \\
\text { maintaining a calm atmosphere. }\end{array}$ & 3.00 & $\mathrm{~A}$ \\
\hline $\begin{array}{l}\text { 5. I. create a positive, achievement- oriented } \\
\text { learning environment. }\end{array}$ & 3.00 & $\mathrm{~A}$ \\
\hline 6. I. create a structured learning environment & 3.00 & $\mathrm{~A}$ \\
\hline $\begin{array}{l}\text { 7. I. create a learning environment that excites } \\
\text { students under the inclusive program. }\end{array}$ & 2.70 & $\mathrm{~A}$ \\
\hline $\begin{array}{l}\text { 8. I. maintain order in different situations that may } \\
\text { arise. }\end{array}$ & 3.00 & $\mathrm{~A}$ \\
\hline 9. I. maintain structured schedule. & 2.90 & $\mathrm{~A}$ \\
\hline $\begin{array}{l}\text { 10. I. maintain flexibility in different situations } \\
\text { that may arise. }\end{array}$ & 3.00 & $\mathrm{~A}$ \\
\hline \multicolumn{1}{|l}{ Over-all Weighted Mean } & $\mathbf{2 . 8 6}$ & \\
\hline
\end{tabular}

Table II presents the total mean distribution of learning environment used/created by the receiving teachers under the Inclusive Education Program at 2.86 with a verbal interpretation of Agree.

Out of the 10 items presented, 6 items received the highest mean score at 3 or agree. While, 2 received a low mean score of $2.40-2.60$ both under the verbal interpretation of Disagree.

The data suggest that the respondents are well grounded with the requirements on creating an atmosphere conducive for learning, which was given importance in the book of Polloway,
Patton, Serna and Bailey (2012), where they believed that "the more a student learns, the more effective is the teacher or the learning climate. If students learn more quickly from one teacher than from one another, the more efficient teacher logically also will be judge as the more effective.

The use of research based instruction is an important data that would help the teachers in creating different instructions and assessment for students' under the Inclusion program.

TABLE III

Mean Percentage Distribution on the Teaching EFFeCtiveness of RECEIVING TEACHERS UNDER THE INCLUSIVE EDUCATION PROGRAM

\begin{tabular}{|c|c|c|}
\hline Items & MEAN & VI \\
\hline $\begin{array}{l}\text { 1. I. create exercises on gross and fine motor } \\
\text { skills that can be transferred into the home by } \\
\text { students under the inclusive program. }\end{array}$ & 2.90 & $\mathrm{~A}$ \\
\hline $\begin{array}{l}\text { 2. I develop activities for Sped students under } \\
\text { the inclusive program focusing on self-help. }\end{array}$ & 2.00 & $\mathrm{D}$ \\
\hline $\begin{array}{l}\text { 3. I. design unit and lesson plans/lesson logs in } \\
\text { consonance with individual evaluation of } \\
\text { students under the inclusive program. }\end{array}$ & 2.10 & $\mathrm{D}$ \\
\hline $\begin{array}{l}\text { 4. I includes "all" children in the learning } \\
\text { process. }\end{array}$ & 2.90 & A \\
\hline $\begin{array}{l}\text { 5. I am able to give the proper assessment for } \\
\text { Sped students under the inclusive program. }\end{array}$ & 2.50 & $\mathrm{D}$ \\
\hline $\begin{array}{l}\text { 6. I am able to implement unit and lesson } \\
\text { plans/lesson } \operatorname{logs} \text { using } \text { differentiated } \\
\text { instruction.. }\end{array}$ & 2.80 & A \\
\hline $\begin{array}{l}\text { 7. I am able to write a comprehensive narrative } \\
\text { report. }\end{array}$ & 2.80 & $\mathrm{~A}$ \\
\hline $\begin{array}{l}\text { 8. I show creativity and uses technique in an } \\
\text { inclusive setting. }\end{array}$ & 2.60 & A \\
\hline $\begin{array}{l}\text { 9. I am able to immediately adjust to different } \\
\text { situations under the an inclusive setting. }\end{array}$ & 2.80 & A \\
\hline $\begin{array}{l}\text { 10. I continue to enhance Sped students skills on } \\
\text { socialization. }\end{array}$ & 2.00 & $\mathrm{D}$ \\
\hline Overall Weighted Mean & 2.54 & $\mathrm{~A}$ \\
\hline
\end{tabular}

Table III presents the total mean score of teaching effectiveness of receiving teachers under the Inclusive Education Program at 2.54 with a verbal interpretation of Agree.

The table also reflects that out of the 10 items presented 4 Items received a low score ranging from $2.00-2.50$ with the verbal interpretation of Disagree.

Furthermore. Item No. 1 "I create exercises on gross and fine motor skills that can be transferred into the home by students under the inclusive program. and item No. 4 "I includes "all" children in the learning process" both received the highest mean score of 2.90 with a verbal interpretation of Agree.

However, the results contradicts with the score given to items No. 2 and 10 both receiving the lowest mean score, where teachers are not able to develop activities for students under the inclusive program. Furthermore, the same data reveals that the teachers are not able to develop the socialization skills of the students even if they are able to include "all" the children in the learning process.

Likewise, the teachers are "able to implement unit and lesson plans/lesson logs using differentiated instruction" as suggested in Item No. 6.

However it was highlighted under the department order 72 item that teachers should use curriculum modification through 
adaptations and accommodations to foster optimum learning based on the individual's needs and potentials.

Table 4 reveals the total mean score on the personal qualities and characters of receiving teachers under the inclusive education program at 2.98 with a verbal interpretation of Agree.

Out of the 10 items presented only item No. 3 "I shows extreme patience with the students" received the highest mean at 3.40 with the verbal interpretation of Strongly Agree, and the rest of the items fell under Agree. The items focuses on the effectiveness of teacher in managing the classroom environment and showing positive characteristic relevant in the creation of an ideal classroom instruction.

Which was ably supported by to Danielson (1991) as cited by Nougaret, Scruggs and mastropieri, (2005) where mentioned that "effective teachers expertly manage the classroom environment"

5. What can be suggested to improve the offering of the Inclusive Education Program of the Division of Surigao?

The suggestions made by the respondents focuses only on one thing and that is for the teachers to have the necessary trainings for Inclusive Education.

\section{- Sufficient Training To All TeAchers AND RELEVANT SEMINARS TO UPGRADE TEACHERS COMPETENCIES}

\section{CHAPTER V CONCLUSION}

The respondents are considered knowledgeable about the existing inclusive education program of DepEd however they lack relevant trainings to improved their skills on how to handle students with special needs. Budget and priorities are said to be the reason.

The respondents are considered effective and well-grounded in creating an atmosphere conducive for learning. However, it is important to point out that there are items that are considered relevant to instruction that were not given importance. Hence, the difficulty in properly assessing and giving intervention foe special students are not crafted.

The respondents are not well versed in using differentiated instruction" as such, students are having difficulty understanding the lessons much more take part in the activity appropriate for the existing conditions in class.

Furthermore, sufficient training for teachers of the Inclusive education program should be done to really address the needs of the program and of the students.

\section{TABLE IV}

MeAn PERCENTAge Distribution of the PERSONAL QuALITIES AND CHARACTERS OF RECEIVING TEACHERS UNDER THE INCLUSIVE

\section{EDUCATION PROGRAM}

\begin{tabular}{|l|c|c|}
\hline Items & MEAN & VI \\
\hline $\begin{array}{l}\text { 1. I always motivate students to realize high } \\
\text { academic and behavioral standards. }\end{array}$ & 3.00 & $\mathrm{~A}$ \\
\hline $\begin{array}{l}\text { 2. I do not have difficulty adjusting to different } \\
\text { learning needs and learners }\end{array}$ & 2.80 & $\mathrm{~A}$ \\
\hline 3. I. shows extreme patience with the students. & 3.40 & SA \\
\hline 4. I create expectations through a daily routine. & 2.90 & $\mathrm{~A}$ \\
\hline 5. I do not lose my tempered in class. & 2.90 & $\mathrm{~A}$ \\
\hline 6. I show a genuine love and joy for children. & 3.00 & $\mathrm{~A}$ \\
\hline $\begin{array}{l}\text { 7. I am able to show maturity in dealing with } \\
\text { different situations. }\end{array}$ & 3.00 & $\mathrm{~A}$ \\
\hline $\begin{array}{l}\text { 8. I am always punctual in the submission of } \\
\text { requirements. }\end{array}$ & 2.90 & $\mathrm{~A}$ \\
\hline $\begin{array}{l}\text { 9. I collaborate with parents of children with special } \\
\text { needs and community, building trust and respecting } \\
\text { confidentiality. }\end{array}$ & 2.90 & $\mathrm{~A}$ \\
\hline $\begin{array}{l}\text { 10. I recognize the obligations of the trust placed in } \\
\text { them. }\end{array}$ & 3.00 & $\mathrm{~A}$ \\
\hline \begin{tabular}{l} 
Overall Weighted Mean \\
\hline
\end{tabular} & 2.98 & $\mathrm{~A}$ \\
\hline
\end{tabular}

\section{REFERENCES}

[1] Hallahan, Kauffman and Pullen (2012) Exceptional learners: An Introduction to Special Education. Pearson College Division.

[2] Nougaret, André A; Scruggs, Thomas E; Mastropieri, Margo A (2005) . Does Teacher Education Produce Better Special Education Teachers?. Exceptional Children 71.3 https://doi.org/10.1177/001440290507100301

[3] Polloway, Patton, Bailey and Serna (2012) Strategies for Teaching Learners with Special Needs, Student Value Edition. Pearson College Division.

[4] http://www.deped.gov.ph " Inclusive Education as a Strategy for Increasing Participation Rate of Children " retrieved Dec. 14, 2017

[5] Hodkinson, Alan (2016) Key Issues in Special Educational Needs \& Inclusion. Sage Publication Ltd. Olive Yard, London

[6] Woodstock, Stuart \& Valle, Wilma (2010) The Potential To Learn: PreService Teachers' Proposed Use Of Instructional Strategies For Students With A Learning Disability; Contemporary Issues in Education Research 27-38 https://doi.org/10.19030/cier.v3i10.236

\section{About Author (s):}

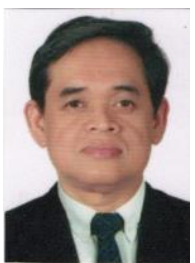

"In this era where exclusivity is being challenged, we have to start to assess why are we in education, our real purpose?

We need to learn to see that all are equal in life and opportunities. We need to embrace the changes taking place in our system to help more of those who are in need".

-John Infante jr. 